Portland State University

PDXScholar

Spring 6-10-2016

\title{
Examining Generational and Gender Differences in Parent-Young Adult Child Relationships During Co- residence
}

Lauren Elizabeth Ferguson

Portland State University

Follow this and additional works at: https://pdxscholar.library.pdx.edu/open_access_etds

Part of the Family, Life Course, and Society Commons

Let us know how access to this document benefits you.

Recommended Citation

Ferguson, Lauren Elizabeth, "Examining Generational and Gender Differences in Parent-Young Adult Child Relationships During Co-residence" (2016). Dissertations and Theses. Paper 3029.

https://doi.org/10.15760/etd.3024

This Thesis is brought to you for free and open access. It has been accepted for inclusion in Dissertations and Theses by an authorized administrator of PDXScholar. Please contact us if we can make this document more accessible: pdxscholar@pdx.edu. 
Examining Generational and Gender Differences in Parent-Young Adult Child Relationships During Co-residence

by

Lauren Ferguson

A thesis submitted in partial fulfillment of the requirements of the degree of

\author{
Master of Arts \\ in \\ Sociology
}

Thesis Committee:

Emily Shafer, Chair

Lindsey Wilkinson

Melissa Thompson

Portland State University

2016 


\begin{abstract}
Young adults of the twenty-first century face a long path to adulthood marked by uncertainty and lack of stability. In response, young adults are heading back to or failing to leave their family homes in higher numbers than generations before (Jacobsen and Mather 2011; Qian 2012). These macro-level trends bring about questions about their impact on family relationships as well as how these relationships have evolved over time. My thesis investigates parent-child relationships during co-residence with a specific focus on generation and gender differences. Through secondary data analysis of the National Survey of Families and Households, I explore how parent-child relationships during coresidence differ between parents of Generation Xer young adults (born between 19651980) and Millennial young adults (born between 1981-1996). Additionally, I examine gender differences between these two generational cohorts. My findings offer support that intergenerational relationships are not necessary closer, but look different for parents of Millennials as compared to Generation Xers. I also find that there are significant gender differences between mothers and fathers of Generation Xers versus those of Millennials. I find that mothers of Generation Xers report more time shared with coresiding young adults and increased frequency of perceived emotional support from their child than fathers; yet, fathers of Millennials report more perceived support than mothers. I suggest these findings offer support for the notion that gendered roles play out into young adulthood and potentially have more flexibility for fathers across time. As the economic and social landscape continues to change and present more uncertainty, family relationships become a form of social security; thus it becomes increasingly important to understand these dynamics. My findings are significant as they contribute to a better


understanding of parent-child relationships over time and offer discussion on the potential implications. 


\section{Acknowledgements}

I would like to thank my entire committee for their feedback and guidance throughout the thesis development process. I owe a special thank you to my chair, Dr. Emily Shafer, for endlessly teaching and supporting me professionally and personally

during each chapter of the graduate school and thesis adventures. Finally, I owe endless gratitude to my moral support team of family, friends, and fellow Sociology cohort members. 
Table of Contents

ABSTRACT I

ACKNOWLEDGEMENTS

III

CHAPTER 1: INTRODUCTION 1

CHAPTER 2: LITERATURE REVIEW 5

THE CHANGING COURSE OF THE AMERICAN FAMILY 5

CHANGING FAMILY LIFE COURSE AND GENDER

CO-RESIDENCE AND THE PARENT-CHILD RELATIONSHIP

GENERATIONAL DIFFERENCES AND CO-RESIDENCE 12

RESEARCH QUESTIONS AND HYPOTHESES

CHAPTER 3: METHODS 16

DATA 16

MEASURES

ANALYTIC STRATEGY

20

CHAPTER 4: RESULTS 22

CHAPTER 5: DISCUSSION 26

GENERATION XERS VERSUS MILLENNIALS: PARENT PERCEPTION OF RELATIONSHIP WITH CORESIDING YOUNG ADULT

GENDER AND PARENT-YOUNG ADULT RELATIONSHIPS DURING CO-RESIDENCE

CHAPTER 6: CONCLUSION 
TABLE 1: SAMPLE CHARACTERISTICS AND MEAN DIFFERENCES

TABLE 2: PARENT-CHILD RELATIONSHIP BY GENDER AND GENERATION

TABLE 3. OLS REGRESSION RESULTS

39 
FIGURES

FIGURE 1: SAMPLE DESCRIPTION

40

FIGURE 2: GENERATIONAL DIFFERENCES IN SHARED TIME WITH CO-RESIDING YOUNG ADULT 41

FIGURE 3: GENERATIONAL DIFFERENCES IN SUPPORT FROM CO-RESIDING YOUNG ADULT 


\section{Chapter 1: Introduction}

"Millennials Are Setting New Records_-for Living With Their Parents" (TIME Magazine 2015). "Like Kim Kardashian, many millennials living with their parents" (Market Watch 2015). “Hey Millennials: It's Cool to Live With Your Parents” (The Federalist 2015). "Why Do So Many Millennials Live With Their Parents? Two Theories: Marriage and Debt” (Slate Magazine 2015). The media headlines are clear: more millennials are living with their parents during young adulthood than ever before. And empirical research supports the media's claims. In 1960, $65 \%$ of men and $77 \%$ of women left home, owned a house, finished school, got married, had a child, and claimed to be financially independent by age 30 . Forty years later in 2000 , those percentages dropped to $31 \%$ and $46 \%$ for men and women, respectively (Furstenberg et al. 2004). The literature suggests that the lack of stable employment, insurmountable student debt, and changing cultural norms around marriage and childbirth have led to these changes and collectively created a long and twisted path to adulthood for Americans ages 18-30 (Settersten and Ray 2010).

What it means to be a young American has dramatically shifted in the last fifty years and, as a result, the phenomenon of delayed adulthood has emerged. Delayed adulthood earned it names as young adults began to "delay" the traditional markers of adulthood: secure employment, marriage, childbearing, leaving the parent home, and finishing school (Arnett 2000; Furstenberg et al. 2004). Delayed adulthood significantly impacts parenthood. As young adults delay their own entrance into adulthood, this creates an extended time of parenting for parents of today's young adults. When young adults 
find themselves amidst an identity shift heavily influenced by larger social forces, parents become an important source of stability—not only financially, but emotionally (Bengtson 2001; Parker and Menacse Horowitz 2015; Swartz et al. 2011). Existing work synthesizes literature and offers inferences about how recent demographic shifts impact family relationships (Kahn, Goldschneider, and García-Manglano 2013; Seltzer and Bianchi 2013; Swartz 2009), yet no studies have examined the impact of these societal shifts on parent-young adult relationships using empirical data. In addition, there is a lack of information on the evolving influence parent gender has on parent-young adult relationships. The idea that children are still "children" in need of "parenting" after age 18 is relatively new phenomenon (Arnett 2000). Thus, differences in how mothers and fathers have navigated the extended path to parenthood across time have yet to be explored.

While some of the commentary within the media and academia on delayed adulthood paint it in a negative light, this is not necessarily an accurate depiction of this phenomenon. Rather, the responses to these trends from the media, family, and others simply point to differences in the cultural meaning of adulthood between older generations and today. As compared to the rigid traditional model of education to work to retirement for generations of the twentieth century, young adults of today are provided with more time to earn an education, focus on personal growth, and pursue meaningful career options (Fingerman and Furstenberg 2012; Settersten and Ray 2010). This new culturally defined stage of life has also invited more diversity in the relationships that young adults develop. In addition to developing closer intergenerational relationships, there is evidence that independence during young adulthood influences the formation of 
non-traditional unions outside of the nuclear family such as same-sex marriages, cohabitation, and interracial marriage (Fingerman and Furstenberg 2012; Rosenfeld 2006). It is important for research to better highlight the nature and nuances of relationships shared during young adulthood in order show that this cultural shift in the meaning of adulthood does not necessarily result in lack of motivation or poor life outcomes.

The purpose of my thesis is twofold in response to these gaps. First, I explore differences between generational cohorts in order to better understand family relationships during co-residence across time. More specifically, I intend to uncover how parent-child relationships during co-residence differ between parents of Generation Xers (young adults ages 18-23 born between 1965-1980) and parents of Millennials (young adults ages 18-23 born between 1981-1996). Secondly, I focus on the unique role parent gender plays on parent-young adult relationships during co-residence in order to shed light on the nuanced differences between parents of Generation Xers and Millennials. I focus on the parent respondents - not co-residing young adults themselves - in order to address the aforementioned research gaps. As such, my formal research questions are as follows:

RQ1: How do parent-young adult child relationships during co-residence differ between the Millennial generation and Generation X from the parent's perspective?

H1: Parents will report closer relationships to Millennial children than to Generation Xers. 
RQ2a: How does parent gender influence parent-young adult child relationships during co-residence?

H2a: Mothers will report closer relationships with their young adults during coresidence as compared to fathers.

RQ2b: In what ways might the potential influence of parent gender vary between parents of Millennials as compared to parents of Generation Xers?

H2b: Fathers of Millennials will report closer relationships with their co-residing young adults as compared to fathers of Generation Xers. 


\section{Chapter 2: Literature Review}

\section{The Changing Course of the American Family}

Shifts in family formation over the past several decades have heavily influenced the current state of intergenerational relationships and co-residence. The definition of family continues to evolve with increases of same-sex couples, stepfamilies, or singleparent households (Gerson 2009). Divorce and remarriage result in changed family structures and altered networks of family ties (Lowenstein 2007; Seltzer and Bianchi 2013). Due to these altered networks and greater life expectancy, young adults of today are more likely to live with grandparents or others outside of immediate family giving them greater exposure to intergenerational relationships (Bengtson 2001; Seltzer and Bianchi 2013; Silverstein and Giarrusso 2010). In addition, marriage and childbearing are happening at later ages for today's generation (DeGenova 2008; Newman 2012; Settersten and Ray 2010). In 2011, approximately 23\% of Millennials ages 18-30 were married; in comparison, in $1997,32 \%$ of Generation Xers were married between the same ages (Anon 2011). Adult Millennials also tend to earn less in annual income and grow up in more racially and ethnically diverse communities as compared to Generation Xers (Anon 2015). These changes in family formation and in the economic landscape have led to a stage of life categorized as emerging adulthood (Arnett 2000; DeGenova 2008). Emerging adulthood is characterized by delaying traditional markers of adulthood: secure employment, marriage, childbearing, leaving the parent home, and finishing school (Arnett 2000; Furstenberg et al. 2004). In 2005, half as many young adults achieved all traditional adulthood markers by age 30 as compared to young adults in 
(Settersten and Ray 2010). Due to the turbulent economic environment (Cherlin et al. 2013; Furstenberg et al. 2004), for Millennials particularly, emerging adulthood is marked by uncertainty and lack of stability leading to a greater dependence on families and intergenerational relationships (Bengtson 2001; Newman 2012; Swartz et al. 2011). Families step in to absorb these risks and uncertainties of young adulthood by keeping their doors, wallets, and arms open for longer - thus extending the course of traditional parenthood (Cherlin et al. 2013; Furstenberg et al. 2004; Newman 2012; Qian 2012; Seltzer and Bianchi 2013; Settersten and Ray 2010; Swartz et al. 2011).

\section{Changing Family Life Course and Gender}

The interplay of gender and parenting young adults over time, in particular, is unclear; however, research on broader parenting changes across the past several decades offers insight into how this may play out during young adulthood. Family scholars argue that characterizing generational changes in parenting is complex as both competing structural and behavioral changes have altered parent-child relationships in recent years (Gauthier, Smeeding, and Furstenberg 2011). Parents of today are, in general, argued to be more "child oriented" and less authoritarian than generations before them (Newman 2012; Sayer, Bianchi, and Robinson 2004; Trifan, Stattin, and Tilton-Weaver 2014). The decrease in fertility over the past decades has led to an increase in the attention that both a mother and father can give to children since there are less children that need it (DeGenova 2008; Gauthier et al. 2011). 
While parents of today are suggested to be more involved in comparison to their own parents, a difference between the involvement level of fathers and mothers remains. Despite more similarity in the labor participation of mothers and fathers, mothers have not reduced the amount of time spent with children and spend more time with children than fathers-yet it is important to note that this gap between mothers and fathers has narrowed over time (Bianchi 2000; Sarkisian and Gerstel 2012; Sayer et al. 2004). Bianchi (2000) argues that the stable trends of mother involvement is due to: (1) exaggerating the amount of time in the home that is actually available to children (2) overestimating how much time works takes away (3) failing the recognize that the needs of children have changed considerably and (4) ignoring the changing investment of fathers.

Although the role and investment of mothers has stayed fairly stable over time, fatherhood has not had the same consistency (Marsiglio et al. 2000). There has been a suggested lack of involvement from fathers in the twentieth-first century due to the rise in divorce, absent fathers, and — consequently—mother-led households (Cabrera et al. 2010). At the same time, there is noted increase in father involvement, responsibility, and care within intact families and for fathers who express more egalitarian views of the division of household labor (Bianchi 2000; Cabrera et al. 2010; Davis and Greenstein 2009; Marks and Palkovitz 2004; Silverstein et al. 2002). Fathers also tend to be more involved with biological children and sons (Dahl and Moretti 2008; Raley and Bianchi 2006; Starrels 1994). Therefore, increases in father involvement appear to be highly dependent on family structure and composition; but, in general, fathers are portrayed as secondary caregivers to mothers (Swartz 2009; Wall and Arnold 2007). Marsiglio et al. 
(2000) state that the growing diversity and transitional nature of the experience of fatherhood calls for more research to explore which factors influence the types and intensity of men's commitment to their children.

There are notable gender differentiations between mothers and fathers in regards to intergenerational relationships shared with young adults (Fivush et al. 2000; Logan and Spitze 1996; Starrels 1994; Swartz et al. 2011). Mothers receive more support—both financially and emotionally—from children than fathers as children age (Kahn, McGill, and Bianchi 2011; Price, McKenry, and Murphy 2000). In line with reciprocity perspectives, this is argued to be a result of greater maternal than paternal investment of time, affect, and energy during early childhood years (Rossi and Rossi 1990; Starrels 1994). Mothers take a traditional affective role in ways such as offering advice and comfort whereas fathers provide instrumental forms of support such as monetary assistance during young adulthood (DeGenova 2008; Price et al. 2000; Starrels 1994; Swartz 2009; Trifan et al. 2014). Mothers report being closer to children than fathers and findings have shown that fathers overestimate their involvement with children when compared to the mother's report of the father's involvement (Seltzer and Brandreth 1995; Shapiro 2004; Swartz 2009). In general, gendered parent-child relationships from childhood continue to play out even as families enter a new life stage (Aquilino 1997; Axinn et al 2011; Rossi and Rossi 1990; Ward and Spitze 1996).

If indeed parent-child relationships tend to stay consistent from adolescence (Aquilino and Supple 1991), we can infer that larger parenting patterns might apply to changes in parenting during young adulthood specifically. The time and emotional support mothers give their young adults may stay consistent across time provided that, 
despite larger changes, mothers still devote significant time to children (Bianchi 2000; Gauthier et al. 2011; Sarkisian and Gerstel 2012; Sayer et al. 2004). The relationship is less clear for fathers. Previous findings would suggest that father involvement during young adulthood depends on factors such as marital status, child gender, and biological relationship to the child. However, when we look at both mothers and fathers together, we could predict that the parents and young adults of today will share closer relationships than generations before provided that parents have become and are expected to be more child-oriented (Sayer et al. 2004; Trifan et al. 2014). Newman (2012) asserts that parents and children of today share closer relationships in general. She attributes this to both changes in technology and parenting styles. Today's parents and their children engage in communication via the same modalities and come home to watch the same TV shows together. The style of parenting has shifted towards "parents as friends" for many of today's families so we would expect that parents of today are experiencing closer relationships with their young adult children as compared to the relationship shared with their own parents (Newman 2012).

\section{Co-Residence and the Parent-Child Relationship}

In response to the changing course of young adulthood and economic uncertainty, one of the ways in which families absorb the risks and costs their young adults face is through co-residence (Cherlin et al. 2013; Mitchell 2004; Newman 2012; Swartz et al. 2011). The parent-child dynamics of co-residence have a variety of empirical and theoretical interpretations. Schnaiberg and Goldenberg (1989) coined the term "incompletely launched young adults" to characterize young adults experiencing unexpected economic dependency, failure to become fully autonomous, or meet parental 
expectations which results in moving back to the parental home (Schnaiberg and Goldenberg 1989). This perspective argues that when life norms are not achieved during this stage of life, it creates a strain on young adults and their families resulting in relationship tension. However, as life course norms have shifted over time, a contradiction between this foundational co-residence theory and more recent theories and empirical findings emerges (Lowenstein 2007; Silverstein and Giarrusso 2010).

Intergenerational Solidarity Theory argues that co-residence leads to greater solidarity within the family since it provides an opportunity for cultivation of all social dimensions (affectual, associational, consensual, functional, normative, and structural) that strengthen intergenerational bonds (Bengtson 2001; Silverstein et al. 2002). Ambivalence theory offers a more critical perspective of family ties than Intergenerational Solidarity Theory (Connidis and McMullin 2002). This theory argues families have both warm and antagonistic feeling towards one another creating a discord known as ambivalence (Connidis and McMullin 2002; Pillemer 1998; Silverstein and Giarrusso 2010). Through this lens, family members are in constant negotiation with one another as they balance their agency and expectations set forth for them by themselves, society, and other family members. When the balance is not achieved, it results in ambivalence (Connidis and McMullin 2002; Pillemer 1998; Silverstein and Giarrusso 2010). Exchange and reciprocity theories also center on the concept of balance within the family. These theories explicate that support exchanges are crucial for sustaining bonds within families over time (Kim et al. 2014; Seltzer and Bianchi 2013). As compared to the late twentieth century (1960-1990) when the economic need of elderly parents largely determined co-residence, the economic dependency of young adults appears to be a 
greater determinant in choices to co-reside (Kahn, Goldscheider, and García-Manglano 2013; Newman 2012). As such, parents offering support in the form of co-residence potentially fosters a closer relationship during young adulthood. Reciprocity theories would argue that when parents offer this support during young adulthood, their young adult is much more likely to provide support to them later in life (Silverstein et al. 2002). Thus, co-residence could be a mutually reinforcing form of support within the family, increasing the strengths of bonds over the life course.

Empirical work finds a neutral or positive association between co-residence and quality parent-child relationships (Aquilino and Supple 1991; Johnson 2013; Parker 2012; Ward and Spitze 1996, 2007). Newman (2012) finds that there are benefits to coresidence during young adulthood, which include less surveillance of behavior, more shared interests, and greater mutual emotional support between parent and child than when they were children, all of which could potentially lead to stronger relationships between parents and adult children. Yet, when parents perceive their child as needing too much, parent well-being tends to suffer (Fingerman et al. 2012; Swartz 2009). In comparison to non-co-resident young adults, co-resident young adults give, receive, and perceive more support from their parents (Shapiro 2004; White and Rogers 1997) Relationships also tend to be more positive when young adults are childless, married, and employed, regardless of co-residence status (Belsky et al. 2003). Family culture is another strong influence on parent-child relationships. Familism is defined as the degree of obligation to family members (Bengtson and Roberts 1991; Bengtson 2001; Britton 2013; Hogan, Eggebeen, and Clogg 1993; Swartz et al. 2011). Dynamics of this stage of life look differently for cultures that emphasize familism, especially the obligation of 
children to returning home to care for parents (Britton 2013; Settersten and Ray 2010). Frequency and amount of financial assistance from parents is positively associated with closeness in the parent-child time together; however this is true for both co-residing and non-co-residing young adults as well (Johnson 2013). African American, Latinos, and low-income families are more likely to provide co-residence in place of offering financial support (Berry 2006; Cobb-Clark and Gørgens 2014; Silva 2013).

In sum, these findings highlight that co-residence presents an opportunity for both relationship development and increased stress within families. Whether it is a bonding or stressful time appears to be dependent on several factors including financial situation, familism, and both child and parent demographics. However, there appears to be some consensus that the strongest of these predictors is the relationship of the parent and young adult established during childhood (Aquilino 1991; Newman 2012; Siennick 2013; Silverstein and Giarrusso 2010; Swartz et al. 2011; Ward and Spitze 2007).

\section{Generational differences and Co-residence}

In a foundational generational theory work, Karl Mannheim (1923) proposes that generations are not solely defined by birth year, but rather an identity shaped by patterns of common experience. In other words, a generation becomes one by experiencing the same "data," which shapes how they manage tradition (Mannheim 1923). The historical and political experiences of a generation influence the values important to them, which informs the types of traditions they create to uphold the values. This theory is echoed in how generations see their family relationships. The intergenerational stake hypothesis 
proposes that generations tend to report family relationships differently due to skewed motivations and interests (Birditt et al. 2012; Shapiro 2004). These motivations and interests are shaped by the historical and social events to which they are exposed, as Mannheim proposes. As generations age, the interests and motivations become more aligned based on more shared experience.

In light of these theories, we can predict that different generations will see family relationships differently on account of the social, political, and historical environment they have experienced (Price et al. 2000). Based on this theoretical interpretation coupled with the empirical findings on evolving family norms, I argue that parents of co-residing Millennials will perceive parent-young adult child relationships differently than parents of Generation Xers. Millennials and their families have been exposed to more diversity in family forms and greater uncertainty entering young adulthood (Seltzer and Bianchi 2013; Settersten and Ray 2010). I hypothesize that today's families might recognize how co-residence during young adulthood is no longer straying from family life course norms, but rather a given situation due to the extended path to adulthood as well as a part of the changing definition of family. The societal normalization of returning home suggests that parents of Millennials may experience less of a strain from co-residing with children provided that, as a generation, both Millennials and their parents have been exposed to more family formation changes than previous generations and less strain suggests a closer relationship.

Changes in intergenerational demography invite greater interaction, support, and mutual influence across generations (Bengtson 2001; Lowenstein 2007; Settersten and Ray 2010). As life expectancy increases and parents, on average, have fewer children, 
relationships with children have the potential to last longer and invite more time and closer bonds shared with an individual child (Gauthier et al. 2011; Seltzer and Bianchi 2013). This, in conjunction with the changing nature of young adulthood, opens up a time in which parents and their children could cultivate and strengthen their relationship. Thus it is important to understand the nature and nuances of relationships shared during this unique life transition as well as how it has changed over recent decades so that we can better understand its trajectory.

Research Questions and Hypotheses

RQ1: How do parent-young adult child relationships during co-residence differ between the Millennial generation and Generation X from the parent's perspective?

H1: Parents will report closer relationships to Millennial children than to Generation Xers.

RQ2a: How does parent gender influence parent-young adult child relationships during co-residence?

H2a: Mothers will report closer relationships with their young adults during coresidence as compared to fathers. 
RQ2b: In what ways might the potential influence of parent gender vary between parents of Millennials as compared to parents of Generation Xers?

H2b: Fathers of Millennials will report closer relationships with their co-residing young adults as compared to fathers of Generation Xers. 


\section{Chapter 3: Methods}

\section{Data}

Data are from Wave 2 and Wave 3 of the longitudinal National Survey of Families and Households [NSFH], a national multi-stage area probability sample of 13,007 persons ages 18 and older that represents the non-institutionalized population of the United States. The national sample includes a main cross-section of households plus an over-sampling of blacks, Puerto Ricans, Mexican Americans, single-parent families, families with stepchildren, cohabiting couples and recently married persons. The unit of observation is individuals (primary respondent) rather than households as the definition of a "household" continually changes so the perspective of one reference individual provides a better description of family history and the experiences of changing family life (Sweet, Bumpass, and Call 1988). Recruitment consisted of mailing an introductory letter to each home identified in the multi-stage sample. A study screener then visited the home for a screening interview and asked, "Tell me everyone who lives here now, including yourself. Include everyone that stays here half time or more" to obtain a household roster. For the oversample, the screener had the additional task of determining whether or not the family was eligible for oversampling selection criteria. The primary respondent was then selected from this household roster via a pre-printed selection table. NSFH consist of both an interview conducted in-person and a self-administered questionnaire to capture information on sensitive topics. A questionnaire was also given to the spouse of the primary respondent at Wave 1 and a phone interview was administered at Waves 2 and 3. My analysis does not include any responses from the spouse questionnaires. Respondents were compensated $\$ 10$ for their time. 
Wave 1 was collected in 1987-1988, Wave 2 was collected in 1992-1994, and Wave 3 was completed in 2001-2003. Wave 2 has an overall response rate of $77 \%$ from Wave 1 respondents. Due to budgetary constraints, Wave 3 only collected information from a sub-sample of participants with focal children and has an overall response rate of 57\% (Sweet and Bumpass 2002). Parents, spouses, and eligible focal children (over age 18) were interviewed at Wave 3. Thus, not all respondents in Waves 1 and 2 are parents, however Wave 3 respondents are all parents. I selected the NSFH dataset based on its relevance and ubiquity within the co-residence literature. Even though it is slightly outdated, its depth and exhaustive nature make it a valuable tool in uncovering the complexities of family life - especially emotions during unique situations such as coresidence in young adulthood (Seltzer and Bianchi 2013).

\section{Sample}

The unit of analysis is parent householders with a co-residing young adult (ages 18-23) at NSFH Wave 2 and 3. I use Pew Research Center's distinction of Generation X and the Millennial generation to define the cohorts. Generation Xers are those born between 1965-1980 and the Millennial generation are those born between 1981-1996 (Parker et al. 2015). NSFH asks one parent a variety of questions about their relationship with a focal child ages 18-23 years old at both waves. The focal child is a randomly selected child living in the household at Wave 1 about whom parents respond on parenting issues in each wave of the survey (Sweet and Bumpass 2002). The sample was restricted to young adult focal children currently living at home. Wave 2 represents parents of Generation Xer young adults born between the years 1969 and 1976 (N=952). 
Wave 3 measures relationships shared with Millennial children who were born between 1978 and $1985(\mathrm{~N}=307)$. The final sample represents young adults of each respective generation ages 18-23 living at home born in the earlier half of their generational cohort with slight overlap of Generation Xers in Wave 3, based on the definition of generations provided by the Pew Research Center. The large difference in the sample sizes reflects the difference in sample size between NSFH Wave 2 and NSFH Wave 3. Figure 1 outlines the samples used for analyses

[Figure 1 here]

\section{Measures}

\section{Dependent Variables}

I use two indices informed by the work of Aquilino and Supple (1991) as outcome variables to understand the parent-child relationship: shared time and support from young adult child. I characterize a "closer relationship" as a high level of shared time and high levels of perceived support from the co-residing young adult. I chose these measures as they offer two different perspectives on parent-young adult relationships. The shared time outcome represents a manifest measure whereas support is attempting to capture a latent measure of parent-child relationships (Swartz 2009).

Shared time is an index of three variables that measure the frequency of: 1) time spent with the child in leisure activities, working on something together, or having private talks 2) meals together and 3) especially enjoyable times with child. Response categories for each question included: "More than once a month," "About once a week," "1 to 3 times a month," "Less than once a month," and "Not at all." Each of the three variables in the index were recoded with a value of ' 0 ' for "Not at all" up to a value of ' 5 ' 
for "More than once a month." The three measures were summed to create a scale from 0 to 15 in which a higher score represents more time spent with the co-residing young adult (Chronbach's alpha $=.8191$ for Generation X sample; Chronbach's alpha $=.8278$ for Millennial sample).

Support from child is an index of two variables that measure likelihood of the parent talking to child if 1) parent felt depressed or unhappy and 2) parent had a major decision to make. Response categories included: "Definitely would," "Probably would," "About a 50-50 chance," "Probably would not," and "Definitely would not." The two questions were recoded so that "Definitely would not" was given a value of ' 0 ' up to a value of ' 5 ' for "Definitely would." The variables were then summed to create a scale from 0-10 in which a higher value represents greater likelihood to seek support from the co-residing young adult (Chronbach's alpha $=.7887$ for Generation X sample;

Chronbach's alpha $=.7706$ for Millennial sample).

Independent and Control Variables

The primary independent variables of interest are generation and parent gender Parent gender is reported as a binary measure (male or female). Female serves as the reference category. Regression models include controls for age, socioeconomic status, race, health, marital status, and number of children in the household. Each of these demographic factors have proven to be influential cultural, economic, and normative factors on parents and children during co-residence thus are important to control for in order to understand the effect of sex alone (Aquilino 1997; Berry 2006; Britton 2013; 
Newman 2012; Price et al. 2000; Seltzer and Bianchi 2013; Silverstein and Bengtson 1997; Ward, Deane, and Spitze 2013).

Parent socioeconomic status is captured by both income and education. Respondents reported income as the total income received before taxes and deductions. In order to compare the income across generations, income measures are calculated using the constant 2003 dollars value to account for inflation - the final year individuals were surveyed (Bureau of Labor Statistics n.d.). Income was then recoded into three categories: Low-income (0-\$25,000) middle income $(\$ 25,001-\$ 75,000)$, and high income (\$75,001 and over) (Proctor and Dalaker 2002). Middle income serves as the reference category. Years of education were recoded into an ordinal measure: less than high school (reference), high school diploma, some college, college degree, and graduate degree.

Parent race was recoded into four categories: non-Hispanic Black, non-Hispanic White (reference), Hispanic, or Other. Health status is measured as self-reported health on a scale from 1 to 5 in which 1 represents "Very poor" up to "Excellent." Marital status was recoded into four categories: married (reference), divorced/separated, never married, or widowed. Finally number of children is simply a count of the number of children in the family both living at home and away. Missing values for all measures were eliminated via list-wise deletion.

\section{Analytic Strategy}

I ran descriptive analyses and mean difference comparisons of Generation $\mathrm{X}$ versus Millennial parent characteristics. I also compared the means of the outcome variables between generations. I ran separate analyses by generation since I am primarily interested in the comparison between the two. While using time (Generation Xers vs. 
Millennials) as an independent variable would have been another viable option, the technique I chose allows me to understand the characteristics and young-adult relationships specific to each generation and then make comparisons between the two.

Using OLS regression, I examine the effect of parent gender on the two outcome indices of shared time and support from child for both generations. I attempted to transform outcomes to achieve a normal distribution and estimate OLS models for both outcomes. The shared time outcome achieved normal distribution; however, I was unable to achieve a normal distribution for the support index. To ensure accuracy of the support outcome results, I estimated an ordered logistic regression. The ordered logistic regression results are substantively identical with those estimated using OLS regression. I present results from OLS models for simplicity.

In order to understand how the relationship outcomes differ between the generations, I compare beta coefficients from each regression using the following formula (Paternoster 1998):

$$
Z=\frac{b_{1}-b_{2}}{\sqrt{S E b_{1}^{2}+S E b_{2}^{2}}}
$$

Paternoster et al. (1998) argue that, unlike the commonly used $\mathrm{z}$ test for differences, this equation avoids a negatively biased estimated standard error of difference. This bias is even more pronounced with unequal sample sizes so provided that my sample sizes are quite different between Generation Xers and Millennials, it is important that I use a formula that can help alleviate this bias. 


\section{Chapter 4: Results}

Table 1 displays sample characteristics and the results from mean comparison and chi-square analyses. In terms of differences between the parents of Generation Xers versus Millennials, we see that there are significant differences in parental education, income, racial makeup, and age. Parents of the Millennial sample are less educated overall; however, there is a higher percentage of middle income $(60.19$ vs. $66.67 \%, p \leq$ $.05)$ and high income families $(5.78 \%$ vs. $9.9 \%, p \leq .05)$ in the Millennial sample even when accounting for inflation. There are slightly more Black and Hispanic parents in the Millennial sample; however, while significant, the racial differences are not substantive The parents of Millennials have a mean age of 58.72 as compared to a mean age of 46.86 for parents of Generation Xers $(\mathrm{p} \leq .001)$. There are no significant differences in the distribution of mother and fathers, marital status, number of children, and health status.

\section{[Table 1 here]}

My primary research question asks: How do parent-young adult child relationships during co-residence differ between the Millennial generation and Generation X from the parent's perspective? Overall, parents are reporting high amounts of time spent with the co-residing young adults and high levels of perceived support from child, yet there are significant differences in these outcomes between the generations. Parents of Generation Xers report more time spent with their co-residing young adult (11.22) than parents of Millennials (10.19), significant at the $p \leq .001$ level. However, parents of Millennials report greater support from the child as compared to parents of Generation Xers (7.63 vs. 7.27, $\mathrm{p} \leq .05)$. While these results are significantly different, the differences between the means of outcomes between the generations are not substantive. Figures $2 \& 3$ visually display these differences. 
[Figure 2 here]

My secondary research questions ask: (1) how does parent gender influence parent-young adult child relationships during co-residence? (2) In what ways might the potential influence of parent gender vary between parents of Millennials as compared to parents of Generation X? Table 2 illustrates results of multivariate analyses between gender, generation, and the outcome variables. The findings show that both mothers of Generation Xers and Millennials spend more time with their co-residing young adult than fathers (11.62 vs. 10.27 and 10.26 vs. 9.94, respectively). Millennial fathers report more support from the young adult than mothers (7.93 vs. 7.39); however, these results are not statistically significant in a means difference analysis. This is not true for Generation $\mathrm{X}$ fathers. Mothers of Generation Xers perceive significantly $(\mathrm{p}<.001)$ more support $(7.56)$ from the young adult than fathers (6.62).

[Table 2 here]

Table 3 presents the results of the OLS regressions for each generation along with the beta coefficient comparison (critical z-value test) between the regression models.

[Table 3 here]

\section{Parents of Generation Xers}

Parent gender significantly affects the frequency of shared time with co-residing young adult Generation Xers when all other variables are held constant. Fathers spend less time with their co-residing young adults $(b=-1.23, \mathrm{p} \leq .001)$ and also report less support from the young adult $(b=-0.98, \mathrm{p} \leq .001)$ as compared to mothers. The results also suggest that parents who identify as Black or Other spend significantly $(\mathrm{p} \leq .05)$ more time with their co-residing young adult as compared to whites $(b=.85$ and $b=$ 
3.05 , respectively). There is also a significant effect for parents of Generation Xers holding higher education degrees in regards to shared time. Those holding college degrees and graduate degrees spend significantly less time $(\mathrm{p} \leq .05)$ with their co-residing young adult as compared to those with less than a high school education $(b=-1.18$ and $b$ $=-1.26$, respectively). There was no significant influence of other demographic variables on parent-young adult relationships.

\section{Parents of Millennials}

With all other variables held constant, parent gender also appears to have a significant effect in the Millennial sample on perceived support from the co-residing young adult, but not shared time. Fathers of millennials report greater support from the child as compared to mothers $(b=0.56, \mathrm{p} \leq .05)$. The only significant influence on shared time when other variables are held constant is the number of children. As the number of children in the family increases, shared time with the co-residing young adult decreases $(b=-0.17, \mathrm{p} \leq .05)$.

\section{Generation X versus Millennials}

Parent gender has significantly different effects on both shared time and support from child between Generation Xers and Millennials. Both Generation X and Millennial fathers spend less time with co-residing young adults than mothers. The difference between these coefficients ( $b=-1.23$ versus $b=-.36)$ is marginally significant $(z=-1.92)$. In comparison, fathers of Generation Xers report less support than mothers from their coresiding young adult whereas fathers of Millennials perceive greater support $(b=-0.98$ 
versus $b=0.56)$. This difference is highly significant $(z=-4.98)$. Again, while significant, these are not substantive differences.

For shared time, there are also significantly different effects of age $(z=1.77)$, parents that identify their race as other $(z=1.77)$, and parents who hold a college degree $(z=-2.33)$ and graduate degree $(z=1.63)$. For parents of Generation Xers, as age increases, the amount of time shared with the young adult also increases, but the relationship reverses for parents of Millennials. This effect is significantly different. The effect of education is greater for Generation Xers. Higher education is associated with a decrease in shared time for Generation Xers but an increase in the Millennial sample. For support from child, the only other significant difference besides gender is that of income level. The effect of earning more than $\$ 75,000$ has a positive effect $(b=.78)$ on support from child for parents of Generation Xers, yet a negative effect $(b=-.61)$ for parents of Millennials. This effect is also significantly different for parents of Generation Xers $(z=$ 2.61). 


\section{Chapter 5: Discussion}

Generation Xers versus Millennials: Parent perception of relationship with co-residing young adult

My findings suggest that parent-young adult relationships during co-residence have changed over time, most notably in that parents of Generation Xers report more time shared time with the co-residing young adult whereas parents of Millennials report more perceived support from their young adult child. I hypothesized that parents of Millennials would report closer relationships with their co-residing young adults than parent of Generation Xers. My hypothesis was partially supported. While parents of Millennials do not report spending more time with young adults, they perceive support from the co-residing young adult at higher levels than parents of Generation Xers. I argue this implies that parents may be engaging in different types of relationships with coresiding young adults. It is important to highlight that although my findings were significant, these differences were not substantive between the groups and the interpretation of my findings must be taken in this context.

The literature supports this conclusion. Riley (1983) theorizes that an aging modern society creates kinship structures that are no longer formed from obligation, but from latent relationships that are created and recreated over time. These latent relationships move beyond the idea that simply "being family" creates a deep and unequivocal bond. Rather the latent relationships of today's families are characterized by reciprocal exchanges (Newman 2012; Riley 1983; Swartz 2009). The uncertainty and less structured life course norms of the twenty-first century has produced this need for greater exchange between generations (Bengtson 2001; Cherlin et al. 2013; Lowenstein 2007; 
Settersten and Ray 2010). In response, perhaps parents of Millennials are more willing to engage in peer-like relationships with young adults than earlier generations in order to facilitate exchange and reciprocity and co-residence may be setting the stage to do so (Kim et al. 2014; Newman 2012; Silverstein and Giarrusso 2010). While my findings hint at this possibility from the parent's perspective, to confirm this assertion, more research is needed that also considers the perspective of the young adult in order to gauge if the relationship is truly reciprocal.

\section{Gender and parent-young adult relationships during co-residence}

The results indicate that mothers and fathers experience relationships with their young adults differently during co-residence. I hypothesized that mothers will report closer relationships with their young adults during co-residence as compared to fathers and that fathers of Millennials will report closer relationships with their co-residing young adults as compared to fathers of Generation Xers. Again, my hypotheses were partially supported. Overall, fathers report less time spent with co-residing young adults than mothers for both generations. Yet, fathers of Millennials report significantly greater support from co-residing young adults than mothers of Millennials. Fathers of Millennials also report greater support from young adult as compared to fathers of Generation Xers. . I interpret my findings to support the notions that: (1) changes in gendered parenting roles from youth and adolescences may stay consistent into young adulthood (2) the gendered roles of parents of young adults have become more fluid over time (3) the fluidity of gender roles over time is less true for mothers than fathers. 
My findings echo previous work that propose gendered family norms continue to play out during young adulthood (Aquilino 1997; Axinn et al 2011; Rossi and Rossi 1990; Ward and Spitze 1996). They also give insight into what little is known about changes in young adulthood parenting. I contend that the over-time trends may be the same as those noted in changes parenting children under age 18 (Bianchi 2000; Sarkisian and Gerstel 2012; Sayer et al. 2004). Specifically, we see that mothers still, overall, spend more physical time with their children in young adulthood, yet there is a notable change in the type of relationship that fathers share. The difference between fathers of Generation Xers versus Millennials in regards to perceived support from the young adult also provides support for this interpretation. This finding echoes the idea that today's parents might engage in a form of reciprocal exchange with young adults than earlier generations (Newman 2012; Riley 1983; Swartz 2009; Trifan et al. 2014), but it also infers that this may be more true for fathers than for mothers.

Over the past several decades, gendered parenting roles have deviated from the traditional narrative. Gerson (2009) comments that today's families are more likely to reflect a concept called gender-flexibility, which means that they are willing to negotiate roles for family members beyond traditional gender ideologies. In young adulthood parenting, this would mean that mothers would stray from the role of the affective caregiver and the father would deviate from providing instrumental means of support such as monetary assistance (DeGenova 2008; Price et al. 2000; Starrels 1994). Provided that fathers of Millennials perceive support from young adults significantly more than fathers of Generation Xers, we see a stray from the role of instrumental support over time. I argue this provides support for this theory of gender-flexibility. The theory of 
gender-flexibility also elucidates the finding that parent gender was a significantly different predictor of relationships with co-residing young adults for parents Generation Xers compared to parents of Millennials. Gender-flexibility would suggest that these gendered differences could be more enforced for parents of Generation Xers than parents of Millennials.

Yet, at the same time, the role of mothers has been less fluid over time than the role of fathers. Mothers are, for the most part, still expected to both "cultivate and supervise" children whereas the role of the father is less consistent and dependent upon other factors (Cabrera et al. 2010; Sayer et al. 2004; Wall and Arnold 2007). The role that mothers take within the home could also explain why fathers are spending less time with their co-residing young adults. Hochschild and Manchung (1989) argue that women play a greater role in maintaining kin networks within the home and also emotionally "hoard" their children. In this sense, mothers may also serve as the gatekeepers in how intergenerational relationships are formed within the home (Hogan et al. 1993; Logan and Spitze 1996; Swartz 2009). My findings insinuate that this relationship carries forward into young adulthood.

In sum, the larger changes in family relationships and roles across time play out during young adulthood co-residence. As mentioned previously, the literature on the evolution of parenting young adults is sparse due to the fact that this is a newly defined stage of life (Arnett 2000). My research offers unique insight and interpretation of this evolution by focusing on co-residence during young adulthood. Examining parenting during young adulthood co-residence specifically may offer a better interpretation of parenting changes since this situation asks parents to continue to take traditional 
parenting roles such as providing shelter, emotional support, etc. My results hint at a change in parenting during young adulthood co-residence. There is an increase in emotional exchange between the two cohorts implying a change in the types of relationships parent and young adults share. In addition, the notable gender differences between Generation Xers than Millennials collectively suggest an increase in the fluidity of family gender roles, specifically for fathers, during young adulthood co-residence.

While my findings provide some support to this idea that family relationships and the gendered dynamics during co-residence are evolving over time, these findings must be interpreted with caution provided that the composition of co-residing families has shifted between the two generations. Men are now twice as likely as women to live at home (Cherlin et al. 2013; Di, Yang, and Liu 2002; Jacobsen and Mather 2011). Young adults with higher incomes are typically more likely to leave their parents' home sooner and not return whereas individuals with less social mobility or limited access to steady employment are most likely to co-reside (Berry 2006; Di et al. 2002); however the unstable job market, lack of affordable housing, and increase in the contingent job force has narrowed the divide of co-residence rates between social classes as well as education levels (Furstenberg et al. 2004; Kahn et al. 2013; Newman 2012). There is also a significant increase in unmarried individuals living at home; however, this is coupled with the overall decrease and delay in marriage for young adults (Di et al. 2002; Kahn et al. 2013; Mitchell 2004). These findings conclude that the Millennials young adults living at home are more likely to be male, college-educated, unmarried, and perhaps from a middle-class background than Generation Xer young adults. Thus, while my findings are important and offer some interpretation of changes over time, they do not take into 
account these selection issues that results from the complex web of change in coresidence patterns and the resulting face of young adults living at home. 


\section{Chapter 6: Conclusion}

As macro-level forces shape family formation norms, it is important for social science to understand what this means on the micro-level of family relationships (Gerson 2009; Jacobson 2011). These results add to the literature by providing an interpretation of the interplay between parent-young adult relationships and gender as it pertains to parents of Generation Xers and Millennials. My findings offer support that intergenerational relationships are not necessary closer, but look different for parents of Millennials as compared to Generation Xers. The effect of parent gender also appears to be significantly different between Generation Xers than Millennials inferring that gendered roles play out into adulthood and potentially have more flexibility for fathers across time.

There are implications for the relationships that families share during this transitional period. Studies suggest that when parents step in to help financially stretched children they are more likely to receive help from their children later in life (Silverstein et al. 2002). As the economic and social landscape continues to change and present more uncertainty, family relationships become a form of social security. Cherlin et al. (2013) states that during times of uncertainty, "the family is not just passively shocked but also takes steps to become a shock absorber." My results suggest that there is an increased perception of support for parents of the Millennial generation. I argue this offers indication that families are recognizing the need to be "shock absorbers" during young adulthood provided that families are not only supporting their children with a shelter, but also engaging in a deeper level of emotional exchange. Exchange theories and empirical research suggests that providing these types of support during young adulthood could potentially pay off as families age (Silverstein and Giarrusso 2010; Silverstein et al. 
2002; Swartz et al. 2011). In addition, life course theories suggest that American families tend to prefer intergenerational exchanges that allow recipients to keep their autonomy over time (Price et al. 2000; Swartz 2009). However, co-residence and the support that occurs with it involve a sacrifice of autonomy. The increase in co-residence coupled with perceived increased support suggests a de-emphasis in the American value of individualism within the family. Thus there are both practical and theoretical implications to understanding co-residence during young adulthood.

\section{Limitations}

There are several limitations to my study. Most notably, the selection bias issue regarding the differences in the composition of co-residing families between the two generations affects my ability to confidently confirm my hypothesis. For example, my finding regarding more support perceived by fathers than mothers in the Millennial cohort could be, in part, explained by a difference between the cohorts. As noted, men are now more likely than woman to live at home as compared to previous decades (Cherlin et al. 2013; Di et al. 2002; Jacobsen and Mather 2011). In addition, fathers tend to be more involved with sons (Dahl and Moretti 2008; Raley and Bianchi 2006; Starrels 1994). Thus, this finding could simply be due to the fact that there may be more sons living at home in the Millennial cohort. Young adult characteristics were excluded due to too many missing cases for the Millennial sample. The lack of inclusion of controls for young adult characteristics does not allow me to account for these cofounders.

There are also selection bias issues in regards to about whom the parents respond on the outcome variable measures. The questions used in analyses only ask about 
experiences with currently co-residing children and, as such, leave out narratives of previously co-residing children or other siblings. Both of these omitted groups may provide a more comprehensive story of the experience of co-residence and family relationships. In addition, the dataset is relatively outdated and data were collected prior to the Great Recession in the United States-an important determinant of intergenerational co-residence. A newer dataset would be a better representation of young adults that have navigated a period of heightened economic uncertainty. Conversely, given the increased variance of household economic stability during the Great Recession, it could be argued that the data dodge what is likely to be a major confounder. Additionally the technique I selected does not allow me to entirely parse out age versus cohort effects. Since I compare two waves of the same dataset, overall the parents are older thus the noted effects could be due to age differences rather than differences in generational cohort. However, the inclusion of age as a control attempted to account for this limitation.

I initially planned to include other measures of social class such as the parent's perception of the child's economic stability or whether or not the child moved home for economic reasons; however, there were too many missing cases to use these data. I had also hoped to include a control for the parent-child relationship during adolescence, but consistent measures were not available for both the Generation X and Millennial sample. However, Aquilino (1997) finds that parent-child relationships tend to stay consistent from adolescence into early young adulthood so while it would have been interesting to include, it may not have produced a meaningful result or could have led to a less efficient regression. 
Despite these selection bias and sample size issues, my research offers commentary on generational differences and the interplay of gender during young adulthood co-residence as well as a launching point for future research. My findings suggest that there are potential benefits of this phenomenon seen in the form of different relationships shared with Millennials as well as a hint of greater gender flexibility in parent roles as compared to earlier generations. Although the media and popular culture often project dismal headlines on the implications of delayed young adulthood and returning to a parent's basement, these understandings overlook the full story. Not only do they dismiss the opportunities it provides young adults in terms of educational, personal, and career development, but my findings suggest this stage could be offering parents of today's generation the chance to develop different types of multigenerational relationships that could also potentially be outside of traditional gender norms (Fingerman and Furstenberg 2012; Furstenberg et al. 2004; Rosenfeld 2006; Settersten and Ray 2010).

As the definition of young adulthood only continues to be challenged and forced to change in the $21^{\text {st }}$ century, multigenerational relationships will serve as a valuable resource for young adults throughout this change (Bengtson 2001). It is important for family scholars and the social science research community to continually refine our understanding of exactly if and how parents are a resource for young adults and also how young adults could be so for parents. In future research endeavors, I intend to explore these dynamics using newer and more complete data as well as include the perspectives of young adults - both those living at home and independently. My thesis work is only 
one step towards addressing these research needs and contributing to the understanding of co-residence, young adulthood, and family life. 


\section{Tables}

Table 1: Sample Characteristics and Mean Differences

\section{PARENT CHARACTERISTICS}

\begin{tabular}{|c|c|c|c|}
\hline & Gen $X$ & Millennials & Significance \\
\hline & $(N=952)$ & $(N=307)$ & \\
\hline Education & & & $* * *$ \\
\hline Less than high school & 12.29 & 29.64 & \\
\hline HS diploma/GED & 41.81 & 39.09 & \\
\hline Some college & 26.79 & 15.64 & \\
\hline College degree & 10.92 & 10.75 & \\
\hline Graduate degree & 8.19 & 4.89 & \\
\hline \multicolumn{4}{|l|}{ Marital Status } \\
\hline Married & 63.24 & 66.45 & \\
\hline Divorced/Separated & 29.2 & 15.96 & \\
\hline Never married & 6.51 & 2.73 & \\
\hline Widowed & 4.83 & 11.07 & \\
\hline \multicolumn{4}{|l|}{ Sex } \\
\hline Father & 30.78 & 37.79 & \\
\hline Mother & 69.22 & 62.21 & \\
\hline Age & 46.86 & 58.72 & $* * *$ \\
\hline Health & 3.96 & 4.04 & + \\
\hline Number of children & 2.49 & 2.5 & \\
\hline Race & & & $* * *$ \\
\hline White & 75.95 & 74.27 & \\
\hline Black & 17.33 & 17.92 & \\
\hline Hispanic & 6.09 & 6.51 & \\
\hline Other & 0.63 & 1.3 & \\
\hline Income & & & $*$ \\
\hline Low income $(0-\$ 25,000)$ & 34.03 & 23.43 & \\
\hline Middle income $(\$ 25,001-\$ 75,001)$ & 60.19 & 66.67 & \\
\hline High income $(\$ 75,001+)$ & 5.78 & 9.9 & \\
\hline
\end{tabular}

Outcome variables

\begin{tabular}{lrrl}
\hline Shared time (0-15) & 11.22 & 10.19 & $* * *$ \\
Support from child (0-10) & 7.27 & 7.63 & $* *$ \\
\hline
\end{tabular}

$+\mathrm{p} \leq .10 * \mathrm{p} \leq .05 * * \mathrm{p} \leq .01 * * * \mathrm{p} \leq .001$ 
Table 2: Parent-Child Relationship by Gender and Generation

\begin{tabular}{lcccc}
\hline & \multicolumn{2}{c}{ Generation X $^{1}$} & \multicolumn{2}{c}{ Millennial } \\
& Shared time $^{1}$ & Support $^{2}$ & Shared time $^{3}$ & Support $^{4}$ \\
\hline Mothers & $11.62(3.74)$ & $7.56(2.03)$ & $10.26(3.03)$ & $7.39(2.14)$ \\
Fathers & $10.27(3.62)$ & $6.62(2.14)$ & $9.94(2.84)$ & $7.93(2.08)$ \\
\hline Mean difference significance mothers vs. fathers: $(1) \mathrm{p}<.001^{* * * *}(2) \mathrm{p}<001^{* * *}(3) \mathrm{p}=.144(4) \mathrm{p}=590$
\end{tabular}

Mean difference significance mothers vs. fathers: $(1) \mathrm{p}<.001^{* * *}(2) \mathrm{p}<.001 * * *(3) \mathrm{p}=.144$ (4) $\mathrm{p}=.590$ 


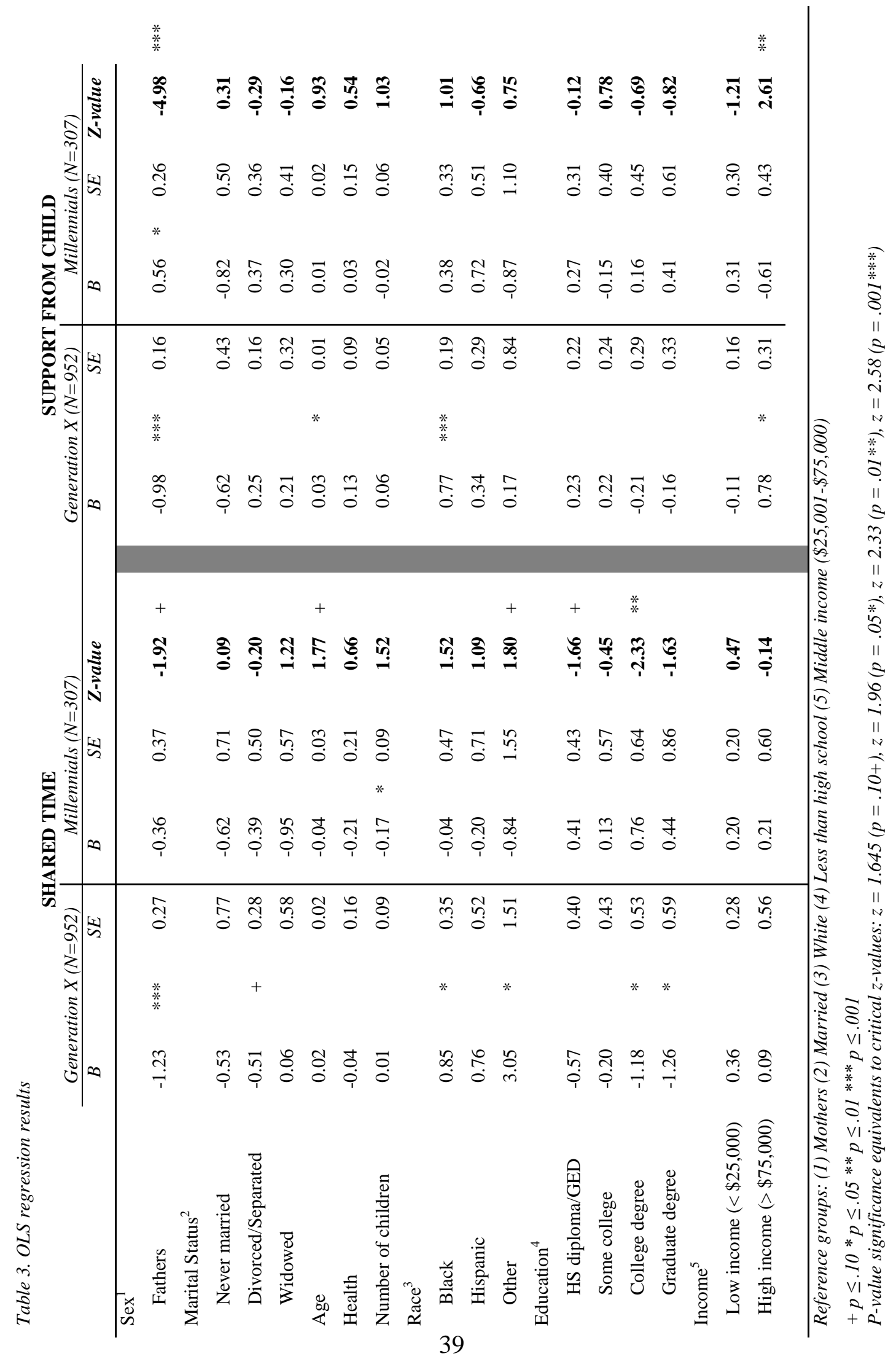




\section{Figures}

\section{Figure 1: Sample Description}

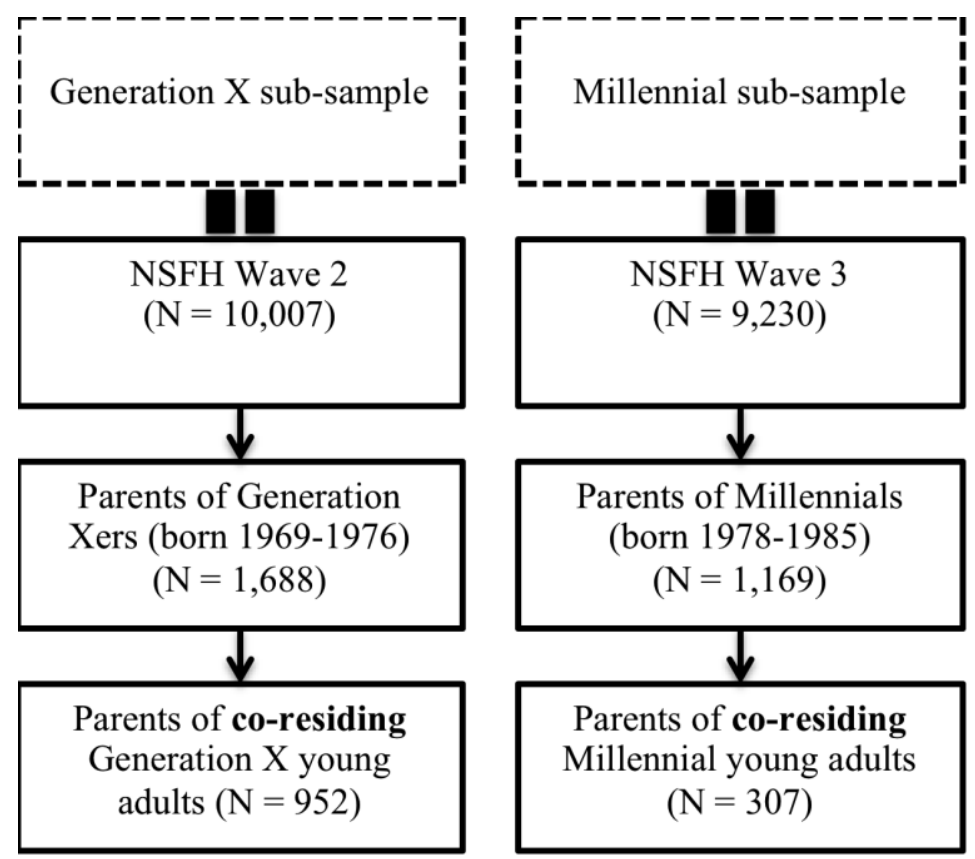


Figure 2: Generational differences in shared time with co-residing young adult

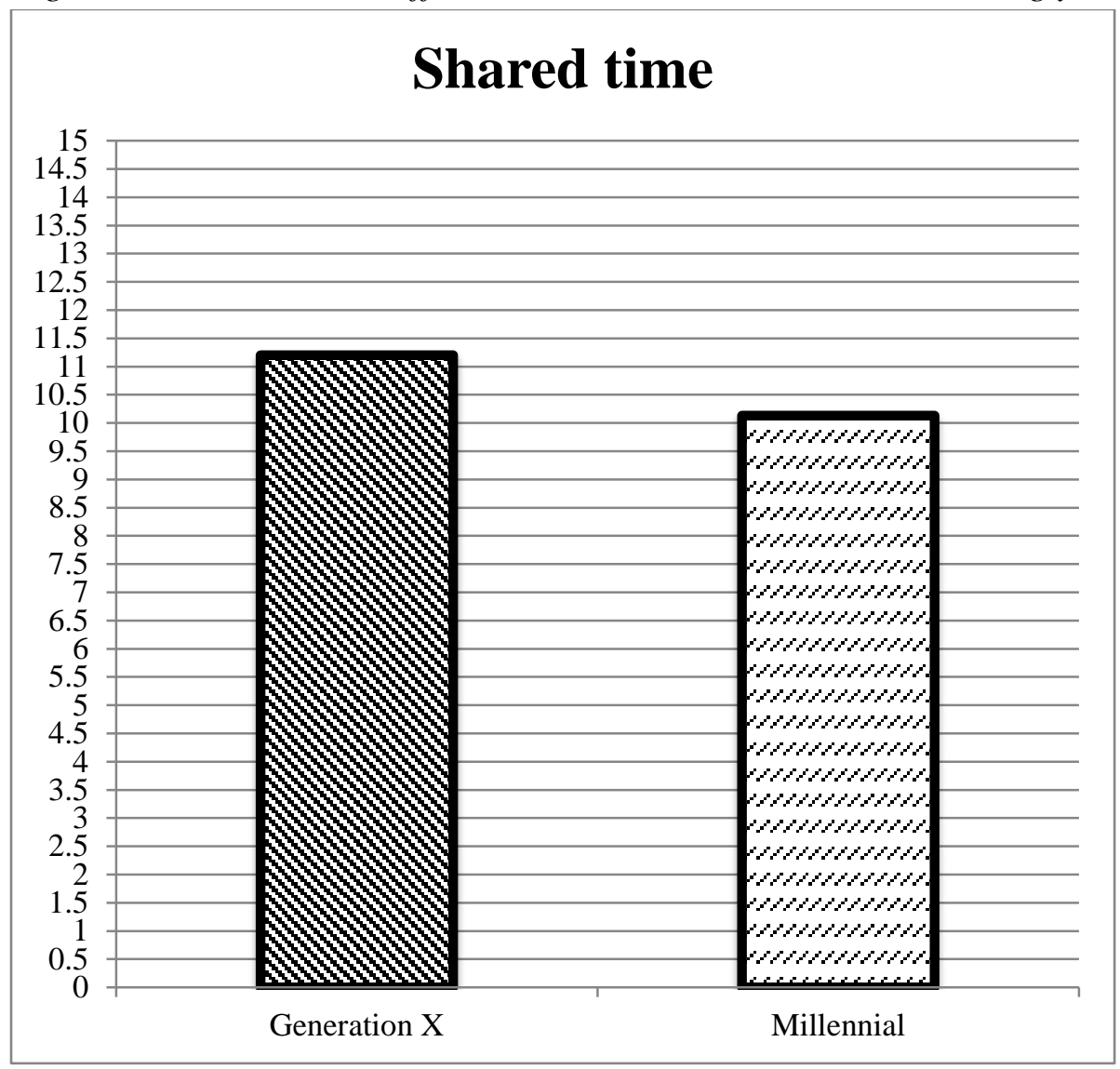

Mean difference significance: Generation X: mean = $11.22(3.76)$; Millennials: mean $=10.19(2.95), \mathrm{p}<.001 * * *$ 
Figure 3: Generational differences in support from co-residing young adult

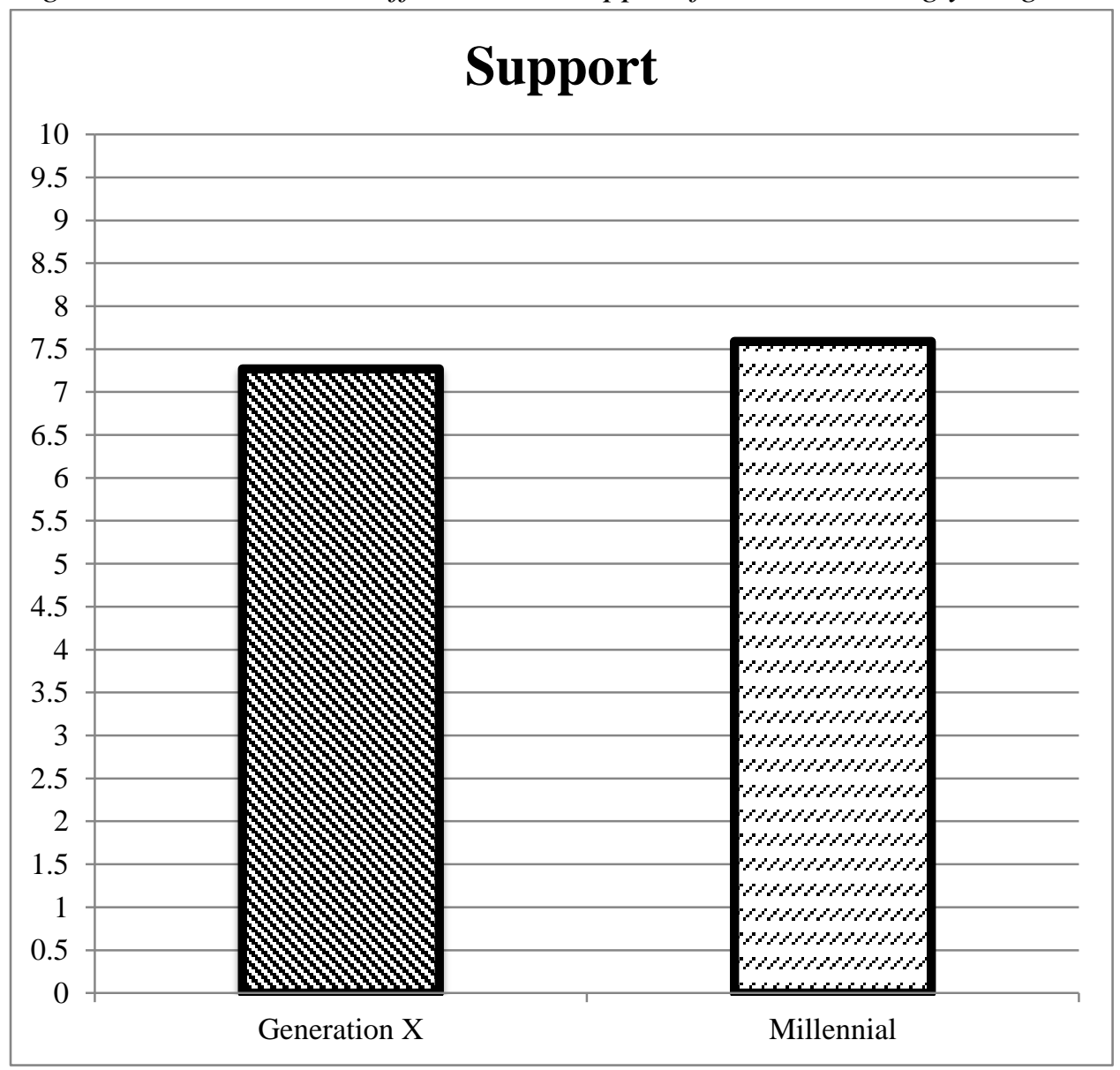

Mean difference significance: Generation X mean = 7.27 (2.11 SD); Millennial mean = $7.64(2.11 \mathrm{SD})$; $\mathrm{p}<.01 * *$ 


\section{References}

Alter, Charlotte. 2015. "Millennials Are Setting New Records--for Living With

Their

Parents." Time Magazine.

Anon. 2011. How Generations Have Changed.

Anon. 2015. Comparing Millennial to Other Generations. Retrieved

(http://www.pewsocialtrends.org/2015/03/19/comparing-millennials-to-othergenerations/\#!16).

Aquilino, W. S. 1991. "Predicting Parents' Experiences With Coresident Adult Children." Journal of Family Issues 12(3):323-42. Retrieved October 7, 2014 (http://jfi.sagepub.com/cgi/doi/10.1177/019251391012003005).

Aquilino, William. 1997. "From Adolescent to Young Adult. a Prospective Study of Parent- Child Relations during the Transition to Adulthood." Journal of Marriage and Family 59(3):670-86.

Aquilino, William and Khalil Supple. 1991. "Parent-Child Relations and Parents' Satisfaction with Living Arrangements When Adult Children Live at Home." Journal of Marriage and Family 53(1):13-27. Retrieved (http://www.popline.org/node/384357).

Arnett, Jeffrey Jensen. 2000. "Emerging Adulthood: A Theory of Development from the Late Teens through the Twenties." American Psychologist 55(5):469-80. Retrieved July 13, 2014 (http://doi.apa.org/getdoi.cfm?doi=10.1037/0003-066X.55.5.469).

Belsky, Jay, Sara R. Jaffee, Avshalom Caspi, Terrie Moffitt, and Phil a Silva. 2003. "Intergenerational Relationships in Young Adulthood and Their Life Course, Mental Health, and Personality Correlates." Journal of family psychology : JFP : journal of the Division of Family Psychology of the American Psychological Association (Division 43) 17(4):460-71.

Bengtson, Vern L. 2001. "Beyond the Nuclear Family: The Increasing Importance of Multigenerational Bonds.” Journal of Marriage and Family 63(1):1-16.

Bengtson, Vern L. and Robert E. L. Roberts. 1991. "Intergenerational Solidarity in Aging Families: An Example of Formal Theory Construction." Journal of Marriage and Family 53(4):856-70. Retrieved (http://www.jstor.org/stable/352993).

Berman, Jillian. 2015. "Like Kim Kardashian, Many Millennials Living with Their Parents." Market Watch.

Berry, Brent. 2006. "What Accounts for Race and Ethnic Differences in Parental Financial Transfers to Adult Children in the United States?" Journal of Family Issues 27(11):1583-1604.

Bianchi, Suzanne M. 2000. "Maternal Employment and Time with Children: Dramatic 
Change or Surprising Continuity?" Demography 37(4):401-14.

Birditt, Kira S., Lauren a Tighe, Karen L. Fingerman, and Steven H. Zarit. 2012. "Intergenerational Quality Across Three Generations." The journals of gerontology. Series B, Psychological sciences and social sciences 67(5):627-38.

Britton, Marcus L. 2013. "Race/Ethnicity, Attitudes, and Living With Parents During Young Adulthood." Journal of Marriage and Family 75(4):995-1013. Retrieved October 15, 2014 (http://doi.wiley.com/10.1111/jomf.12042).

Bureau of Labor Statistics. n.d. "Consumer Price Index Inflation Caluculator." Retrieved (data.bls.gov/cgi-bin/cpicalc.pl).

Cabrera, Natasha J. et al. 2010. "Fatherhood in the Twenty-First Century." Child Development 71(1):127-36.

Cherlin, Andrew, E. Cumberworth, S. P. Morgan, and C. Wimer. 2013. "The Effects of the Great Recession on Family Structure and Fertility." The ANNALS of the American Academy of Political and Social Science 650(1):214-31. Retrieved October 7, 2014 (http://ann.sagepub.com/cgi/doi/10.1177/0002716213500643).

Cobb-Clark, Deborah a. and Tue Gørgens. 2014. "Parents' Economic Support of YoungAdult Children: Do Socioeconomic Circumstances Matter?" Journal of Population Economics 27:447-71.

Connidis, Ingrid Arnet and Julie Ann McMullin. 2002. "Ambivalence and Family Ties: Sociological A Critical Perspective.” Journal of Marriage and Family 64(3):55867.

Dahl, Gordon B. and Enrico Moretti. 2008. "The Demand for Sons." Review of Economic Studies 75(4):1085-1120.

Davis, Shannon N. and Theodore N. Greenstein. 2009. "Gender Ideology: Components, Predictors, and Consequences." Annual Review of Sociology 35(1):87-105.

DeGenova, Mary Kay. 2008. "Parent-Adult Child Relationships.” Pp. 352-69 in Intimate Relationships, Marriages, and Families.

Di, Zhu Xiao, Yi Yang, and Xiaodong Liu. 2002. Young American Adults Living in Parental Homes.

Fingerman, Karen L. et al. 2012. "Helicopter Parents and Landing Pad Kids: Intense Parental Support of Grown Children." Journal of Marriage and Family 74(4):880 96. Retrieved October 15, 2014 (http://doi.wiley.com/10.1111/j.17413737.2012.00987.x).

Fingerman, Karen L. and Frank F. Furstenberg. 2012. "You Can Go Home Again.” New York Times.

Fivush, Robyn, Melissa a Brotman, Janine P. Buckner, and Sherryl H. Goodman. 2000. 
“Gender Differences in Parent - Child Emotion Narratives.” Sex Roles 42:233-53.

Furstenberg, Frank F., Sheela Kennedy, Vonnie McLoyd, Ruben Rumbaut, and Richard Settersten. 2004. "Growing Up Is Harder to Do." Pp. 95-102 in The Context Reader: American Sociological Association.

Gauthier, Anne H., Timothy M. Smeeding, and Frank F. Furstenberg. 2011. "Do We Invest Less Time in Children? Trends in Parental Time in Selected Industrialized Countries Since the 1960s." SSRN Working Paper Series. Retrieved (http://search.proquest.com/docview/1095335632?accountid=17225 \nhttp://ssrn.co $\mathrm{m} / \mathrm{abstract}=1810844)$.

Gerson, Kathleen. 2009. "Changing Lives, Resistant Institutions: A New Generation Negotiates Gender, Work, and Family Change." Sociological Forum 24(4):735-53. Retrieved October 13, 2014 (http://doi.wiley.com/10.1111/j.15737861.2009.01134.x).

Hochschild, Arlie Russell and Anne Manchung. 1989. The Second Shift. Penguin Books.

Hogan, Dennis P., David J. Eggebeen, and Clifford C. Clogg. 1993. "The Structure of Intergenerational Exchanges in American Families.” American Journal of Sociology 98(6):1428.

Howe, Neil. 2010. "A New Parent Generation: Meet Mr and Mrs Gen X." The Education Digesst 67(January):18-23.

Jacobsen, Linda A. and Mark Mather. 2011. Population Bulletin Update: A PostRecession Update on U.S. Social and Economic Trends.

Johnson, Monica Kirkpatrick. 2013. "Parental Financial Assistance and Young Adults' Relationships With Parents and Well-Being." Journal of marriage and the family 75(3):713-33. Retrieved October 15, 2014

(http://www.pubmedcentral.nih.gov/articlerender.fcgi?artid=3734958\&tool=pmcent rez\&rendertype $=$ abstract) .

Kahn, Joan R., Frances Goldscheider, and Javier García-Manglano. 2013. "Growing Parental Economic Power in Parent-Adult Child Households: Coresidence and Financial Dependency in the United States, 1960-2010.” Demography 50(4):144975.

Kahn, Joan R., Brittany S. McGill, and Suzanne M. Bianchi. 2011. "Help to Family and Friends: Are There Gender Differences at Older Ages?" Journal of Marriage and Family 73(1):77-92.

Kim, Kyungmin, Steven H. Zarit, Kira S. Birditt, and Karen L. Fingerman. 2014. "Discrepancy in Reports of Support Exchanges Between Parents and Adult Offspring: Within- and Between-Family Differences." Journal of family psychology 28(2):168-79. Retrieved (http://www.ncbi.nlm.nih.gov/pubmed/24548009).

Logan, John R. and Glenna D. Spitze. 1996. Family Ties: Enduring Relations Between 
Parents and Their Grown Children. Phildelphia: Temple University Press.

Lowenstein, Ariela. 2007. "Determinants of the Complex Interchange among Generations: Collaboration and Conflict." Paper for UN Social Policy Division Expert Group Meeting (October):53-82.

Mannheim, Karl. 1923. "The Sociological Problem of Generations.” Pp. 163-95 in Essays on the Knowledge of Sociology. Taylor \& Francis Books UK.

Marks, Loren and Rob Palkovitz. 2004. "American Fatherhood Types: The Good, the Bad, and the Uninterested." Fathering: A Journal of Theory, Research, and Practice about Men as Fathers 2(2):113-29.

Marsiglio, William, Paul Amato, Randal D. Day, and Michael E. Lamb. 2000. "Scholarship on Fatherhood in the 1990s and beyond." Journal of Marriage and Family 62(4):1173-91.

Mitchell, Barbara A. 2004. "Changing Courses : The Pendulum of Family Transitions in Comparative Perspective."

Newman, Katherine. 2012. The Accordion Family: Boomerang Kids, Anxious Parents, and The Private Toll of Global Competition. Boston: Beacon Press.

Parker, Kim. 2012. The Boomerang Generation: Feeling OK about Living With Mom and Dad. Retrieved (http://www.pewsocialtrends.org/files/2012/03/PewSocialTrends2012-BoomerangGeneration.pdf).

Parker, Kim and Juliana Menacse Horowitz. 2015. "Family Support in Graying Societies: How Americans, Germans, and Italians Are Coping with an Aging Population." (May).

Paternoster, Raymond, Robert Brame, Paul Mazerolle, and Alex Piquero. 1998. "Using the Correct Statistical Test for the Equality of Regression Coefficients." Criminology 36(4):859-66.

Payton, Bre. 2015. "Hey Millennials: It's Cool to Live With Your Parents.” The Federalist.

Pillemer, Karl. 1998. "Intergenerational Ambivalence : A New Approach to the Study of Parent-Child Relations in Later Life." Journal of Marriage and Family 60(2):41325.

Price, Sharon, Patrick McKenry, and Megan Murphy. 2000. "Families Across Time: A Life Course Perspective.” Los Angeles: Roxbury Publishing Company.

Proctor, Bernadette and Joseph Dalaker. 2002. Poverty in the United States.

Qian, Zhenchao. 2012. During the Great Recession, More Young Adults Lived With Parents.

Raley, Sara and Suzanne Bianchi. 2006. "Sons, Daughters, and Family Processes: Does 
Gender of Children Matter?" Annual Review of Sociology 32(1):401-21.

Riley, Matilda. 1983. "The Family in an Aging Society: A Matrix of Latent Relationships.” Journal of Family Issues 4(3):286-308.

Rosenfeld, Michael J. 2006. "Young Adulthood as a Factor in Social Change in the United States." Population and Development Review 32(1):27-51.

Rossi, Alice and Peter Rossi. 1990. Of Human Bonding: Parent-Child Relations Across the Life Course. Hawthorne, New York: Aldine de Gruyter.

Sarkisian, Natalie and Naomi Gerstel. 2012. Nuclear Family Values, Extended Family Lives: The Power of Race, Class, and Gender. New York: Taylor \& Francis Books UK.

Sayer, Liana C., Suzanne M. Bianchi, and John P. Robinson. 2004. "Are Parents Investing Less in Children? Trends in Mothers' and Fathers' Time with Children." American Journal of Sociology 110(1):1-43.

Seltzer, J. A. and Y. Brandreth. 1995. "What Fathers Say about Involvement with Children after Separation." Pp. 166-92 in Fatherhood: Contemporary theory, research, and social policy. Thousand Oaks, CA: Sage.

Seltzer, Judith a. and Suzanne M. Bianchi. 2013. "Demographic Change and Parent-Child Relationships in Adulthood." Annual Review of Sociology 39(1):275-90. Retrieved (http://www.annualreviews.org/doi/abs/10.1146/annurev-soc-071312-145602).

Settersten, Richard and Barbara Ray. 2010. "What's Going on with Young People Today? The Long and Twisting Path to Adulthood." The Future of Children 20(1):19-41. Retrieved October 12, 2014 (http://muse.jhu.edu/journals/foc/summary/v020/20.1.settersten.html).

Shapiro, Adam. 2004. "Revisiting the Generation Gap: Exploring the Relationships of Parent/adult-Child Dyads." International journal of aging \& human development 58(2):127-46.

Siennick, Sonja E. 2013. "Still the Favorite? Parents' Differential Treatment of Siblings Entering Young Adulthood." Journal of Marriage and Family 75(4):981-94. Retrieved October 15, 2014 (http://doi.wiley.com/10.1111/jomf.12048).

Silva, Jennifer M. 2013. Coming Up Short: Working Class in the Age of Uncertainty. Oxford University Press.

Silverstein, Merril and Vern L. Bengtson. 1997. "Intergenerational Solidarity and the Structure of Adult Child-Parent Relationships in American Families." American Journal of Sociology 103(2):429-60.

Silverstein, Merril, Stephen J. Conroy, Haitao Wang, Roseann Giarrusso, and Vern

L. Bengtson. 2002. "Reciprocity in Parent-Child Relations over the Adult Life Course." The journals of gerontology. Series B, Psychological sciences and social 
sciences 57(1):S3-13.

Silverstein, Merril and Roseann Giarrusso. 2010. "Aging and Family Life: A Decade Review.” Journal of Marriage and Family 72(5):1039-58.

Starrels, Majorie. 1994. "Gender Differences in Parent-Child Relations.” Journal of Family Issues 15(1):148-65.

Swartz, Teresa Toguchi. 2009. "Intergenerational Family Relations in Adulthood: Patterns, Variations, and Implications in the Contemporary United States." Annual Review of Sociology 35(1):191-212. Retrieved October 7, 2014 (http://www.annualreviews.org/doi/abs/10.1146/annurev.soc.34.040507.134615).

Swartz, Teresa Toguchi, Minzee Kim, Mayumi Uno, Jeylan Mortimer, and Kirsten Bengtson O'Brien. 2011. "Safety Nets and Scaffolds: Parental Support in the Transition to Adulthood." Journal of Marriage and Family 73(2):414-29. Retrieved October 7, 2014 (http://www.pubmedcentral.nih.gov/articlerender.fcgi?artid=3109900\&tool=pmcent rez\&rendertype $=$ abstract) .

Sweet, James, Larry Bumpass, and Vaughn Call. 1988. The Design and Content of the National Survey of Families and Households.

Trifan, Tatiana Alina, H??kan Stattin, and Lauree Tilton-Weaver. 2014. "Have Authoritarian Parenting Practices and Roles Changed in the Last 50 Years?" Journal of Marriage and Family 76(4):744-61.

Wall, Glenda and Stephanie Arnold. 2007. "How Involved Is Involved Fathering?: An Exploration of the Contemporary Culture of." Gender and Society 21(4):508-27. Retrieved (http://www.jstor.org/stable/27640989\nhttp://www.jstor.org/stable/27640989?seq=

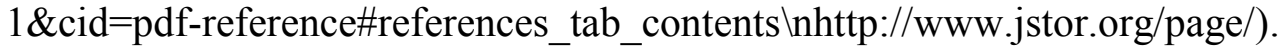

Ward, R. a. and G. D. Spitze. 2007. "Nestleaving and Coresidence by Young Adult Children: The Role of Family Relations." Research on Aging 29(3):257-77. Retrieved December 6, 2014 (http://roa.sagepub.com/cgi/doi/10.1177/0164027506298225).

Ward, R., G. Deane, and G. Spitze. 2013. "Life-Course Changes and Parent-Adult Child Contact." Research on Aging 36(5):568-602. Retrieved (http://roa.sagepub.com/cgi/doi/10.1177/0164027513510325).

Ward, R. and G. Spitze. 1996. "Will the Children Ever Leave?: Parent-Child Coresidence History and Plans." Journal of Family Issues 17(4):514-39. Retrieved October 15, 2014 (http://jfi.sagepub.com/cgi/doi/10.1177/019251396017004005).

Weissman, Jordan. 2015. "Why Do So Many Millennials Live With Their Parents? Two Theories: Marriage and Debt." Slate.

White, L. K. and S. J. Rogers. 1997. "Strong Support but Uneasy Relationships: 
Coresidence and Adult Children's Relationships with Their Parents." Journal of Marriage and the Family 59(18443):62-76. 